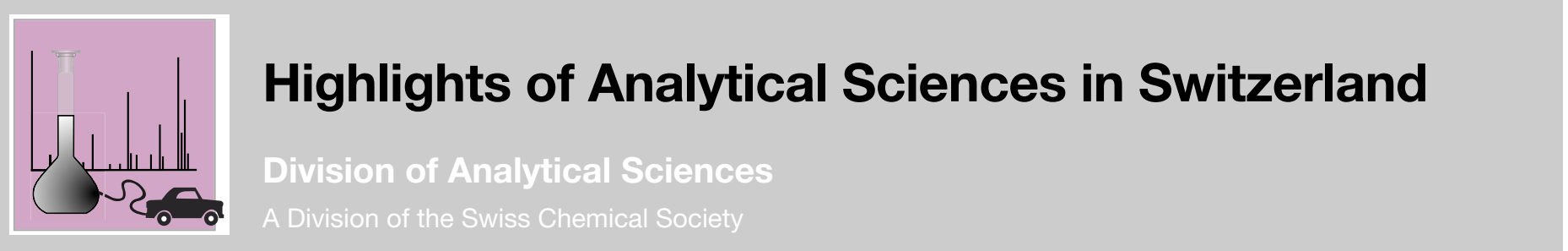

\section{A Fast and Reliable in vitro Method for Screening of Exhaust Emission Toxicity in Lung Cells}

Christoph Bisiga, Sandro Steinera, Jan Czerwinski ${ }^{\text {, }}$ Pierre Comte ${ }^{\mathrm{b}}$, Andreas Mayer ${ }^{\mathrm{c}}$, Alke Petri-Fink ${ }^{\mathrm{a}}$, and Barbara Rothen-Rutishauser ${ }^{\star a}$

${ }^{*}$ Correspondence: Prof. B. Rothen-Rutishausera, Tel.: +41 263009502 , E-mail: barbara.rothen@unifr.ch

${ }^{a}$ Adolphe Merkle Institute, Université de Fribourg, Ch. de Verdiers 4,

$\mathrm{CH}-1700$ Fribourg; ${ }^{\mathrm{b} B e r n}$ University of Applied Sciences, Automotive Engineering, Gwerdtstrasse 5, CH-2560 Nidau; ' ${ }^{\mathrm{TTM}}$, Technik thermischer Maschinen,

Fohrhölzlistrasse 14b, CH-5443 Niederrohrdorf

Keywords: 3D lung cell model · Adverse effects .

Exhaust emission - Exposure system .

Physicochemical properties of exhaust

Pollution by vehicles is a major problem for the environment due to the various components in the exhaust gases, i.e. gaseous and non-gaseous compounds such as particulate matter. Epidemiological studies demonstrate the profound impact of vehicle emissions upon human health. ${ }^{[1]}$ Such studies, however, cannot attribute an adverse effect to a certain exhaust component, which renders decision-making difficult when defining which emission sources should be regulated more stringently.

Reduction in emission of certain exhaust constituents and increased engine efficiency can be measured by technical means (see the Analytical Highlight of Heeb et al. in the next issue of CHIMIA). Standardized protocols for exhaust toxicity assessment are lacking and rely in many aspects on epidemiological and in vivo studies. Reasonable alternatives are in vitro studies using

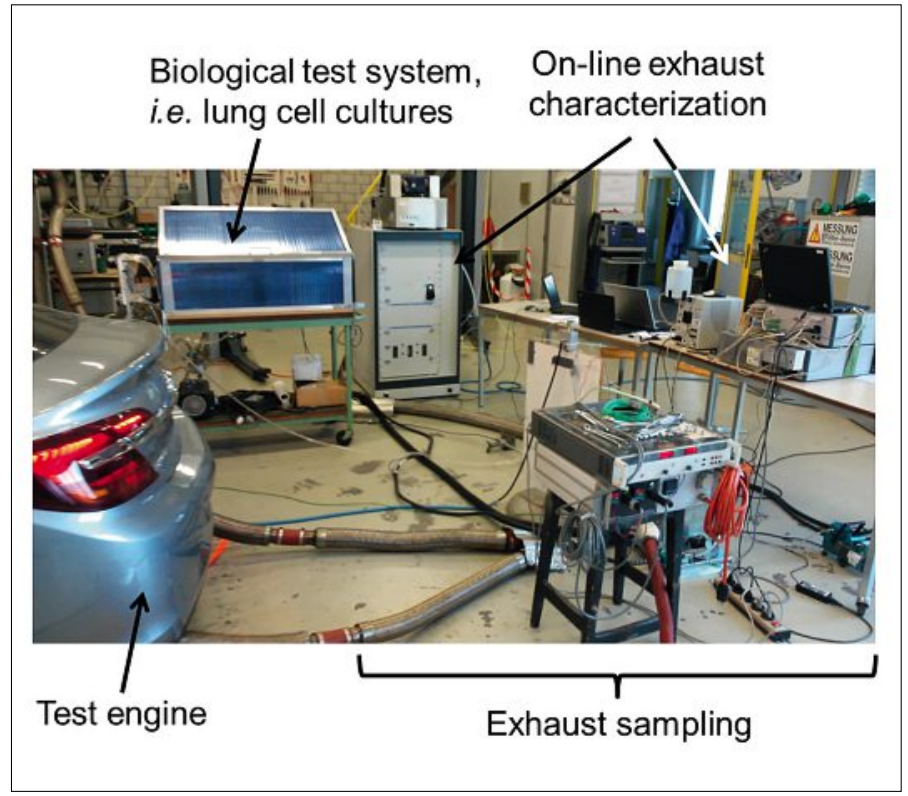

Overview of the exposure system with the engine on the chassis dynamometer, the measuring units and the exposure box. highly standardized cell cultures such as a 3D model of the human airway epithelium composed of epithelial cells and two types of immune cells, i.e. macrophages and dendritic cells. They can be used in combination with an exhaust system for exposure of lung cells to complete engine exhaust. The emission samples of an engine of choice can be taken directly at the exhaust and brought onto the lung cell surface with exhaust characterisation being performed on-line.

The system was established for scooter exhaust and has also been adapted for diesel cars. ${ }^{[2]}$ It yields reproducible results, provides the needed sensitivity for detecting differences in biological responses, and allows for differentiation between effects induced either by gaseous or by particulate components of the complete exhaust. ${ }^{[3]}$

This advanced exposure system is well suited for risk assessment of exhaust emissions as well as for investigations on how engine type, exhaust after-treatment technologies, fuel additives, and fuel types affect acute exhaust toxicity.

\section{Acknowledgements}

This work is financially supported by the Swiss Federal Office for the Environment, Erdölvereinigung EV and VSS lubes, Bern University of Applied Sciences as well as the Adolphe Merkle Foundation.

Received: December 11, 2014

[1] A. J. Ghio, M. S. Carraway, M. C. Madden, J. Toxicol. Environ. Health B 2012, 15,1 .

[2] L. Müller, P. Comte, J. Czerwinski, M. Kasper, A. C. R. Mayer, A. Schmid, L. Rosinus, M. J. D. Clift, S. Steiner, P. Gehr, B. Rothen-Rutishauser, Toxicol. Env. Chem. 2012, 94, 164.

[3] S. Steiner, J. Czerwinski, P. Comte, O. Popovicheva, E. Kireeva, L. Müller, N. Heeb, A. Mayer, A. Fink, B. Rothen-Rutishauser, Atmos. Env. 2013, 81, 380 .

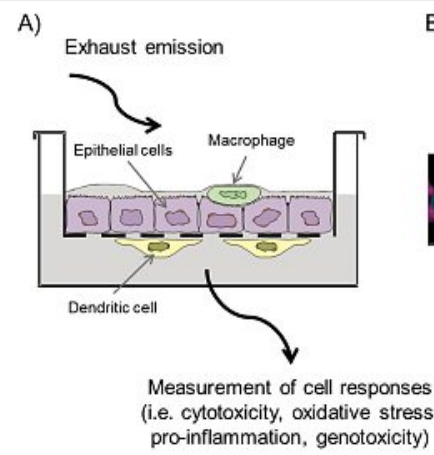

B)

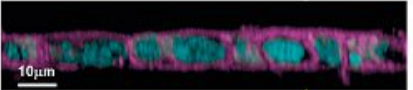

Exposure of lung cell cultures with the exhaust emissions. A) Schematic drawing of the 3D cellular model of the human airway epithelium composed of epithelial cells, macrophages and dendritic cells. The cells as well as the cell culture medium can be sampled to assess various cell responses. B) Laser scanning micrograph (xz-projection) of the epithelial cells grown on a porous filter insert. F-actin is shown in violet, the cell nuclei in light blue. 